УДК 7.072.2:2-526.65(045)

\author{
Ус Вікторія Феліксівна, \\ кандидат технічних наук, \\ доцент кафедри дизайну інтер'єру \\ Національного авіаційного університету \\ yc0869@gmail.com \\ ORCID 0000-0001-7511-4449
}

\title{
ПРІОРИТЕТНІ ПИТАННЯ ЗБЕРЕЖЕННЯ ТА ОХОРОНИ ПРАВОСЛАВНИХ САКРАЛЬНИХ ПАМ'ЯТНИКІВ
}

\begin{abstract}
Мета дослідження полягає в акцентуванні уваги науковців, архітекторів, дизайнерів на невідкладних завданнях охорони й збереження культурної спадщини нашого народу - пам'ятників меморіального сакрального мистецтва, зокрема православних надгробків. Методологія дослідження побудована на поєднанні історичного аналізу становлення та розвитку сакральних меморіальних форм, відомостей мистецтвознавчих джерел 3 архітектури, скульптури та декоративного мистецтва XIX-го - початку XX століття. В статті використано відомості щодо функціонування каменеобробних та металообробних цехових підприємств та спеціалізованих майстерень 3 виготовлення пам'ятників. Вагомим підгрунтям стали архівні документи, світлини, а також авторські обміри вцілілих надгробних пам'ятників на Лук'янівському цвинтарі міста Києва, що надало змогу виокремити найбільш суттєві питання вказаної проблематики. Наукова новизна характеризується аргументацією необхідності розпочати дослідження питань формотворчого процесу православних надгробків періоду другої половини XIX-го - початку XX-го століття, які на сьогодні залишаються не вивченими, формулюванні класифікаційних ознак надгробних пам'ятників, визначенні композиційних, технічних і технологічних аспектів, розкритті ролі формотворчих елементів, що має суттєве значення в справі науково-обгрунтованих методик відновлення, реставрації й проектуванні об'єктів меморіального сакрального характеру. Висновки. Пріоритетні питання збереження та охорони православних сакральних пам'ятників в Україні сформульовані на прикладі дослідження Лук'янівського цвинтаря м. Києва. За зовнішніми ознаками пам'ятників зазначеного періоду встановлено основні типологічні групи, домінантні елементи. В системі якісних критеріїв оцінки форми надгробка пріоритетним є принцип синтезу композиційних, конструктивних та технологічних засобів спорудження надгробків. Вивчення виробів металевої пластики, багато з яких перебуває в залишковому стані, підтверджує, що художньо-декоративні й конструктивні якості металевих форм надгробків являють собою унікальні зразки української сакральної культури. Не менш важливим питанням є дослідження каменярства, яке грунтується на багатовікових традиціях використання каменю під час виготовлення надгробних плит, скульптурних композицій, колон, обелісків, хрестів, ікон, різноманітних зразків дрібної пластики для оздоблення поховань.
\end{abstract}

Ключові слова: сакральна меморіальна пластика, православний надгробок, плита, культурна спадщина, композиція.

Ус Виктория Феликсовна, кандидат технических наук, доцент кафедрь дизайна интерьера, Национального авиачионного университета

Приоритетные вопросы сохранения и охраны православных сакральных памятников.

Цель исследования заключается в акцентировании внимания ученых, архитекторов, дизайнеров на неотложных задачах охраны и сохранения культурного наследия нашего народа - памятников мемориального сакрального искусства, в частности православных надгробий. Методология исследования построена на сочетании исторического анализа становления и развития сакральных мемориальных форм, сведений искусствоведческих источников из архитектуры, скульптуры и декоративного искусства XIX-го - начала XX века. В статье использованы сведения о функционировании камнеобрабатывающих и металлообрабатывающих цеховых предприятий и специализированных мастерских по изготовлению памятников. Весомым основанием стали архивные документы, фотокадры, а так же авторские обмеры уцелевших надгробных памятников на Лукьяновском кладбище города Киева, которое предоставило возможность выделить наиболее существенные вопросы данной проблематики. Научная новизна характеризуется аргументацией необходимости начать исследования по формообразующих процесса православных надгробий периода второй половины XIX-го начала XX-го века, которые сегодня остаются не изученными, формулировке классификационных признаков надгробных памятников, определении композиционных, технических и технологических аспектов, раскрытия роли формообразующих элементов, имеет существенное значение в деле научно-обоснованных методик восстановления, реставрации и проектировании объектов мемориального сакрального х рактеру. Выводы. Приоритетные вопросы сохранения и охраны православных сакральных памятников в Украине сформулированы на примере исследования Лукьяновского кладбища г. Киева. По внешним признакам

(C) Ус В.Ф., 2019 
памятников указанного периода установлены основные типологические группы, доминантные элементы. В системе качественных критериев оценки формы надгробия приоритетным является принцип синтеза композиционных, конструктивных и технологических средств сооружения надгробий. Изучение изделий металлической пластики, многие из которых находится в остаточном состоянии, подтверждает, что художественно-декоративные и конструктивные качества металлических форм надгробий представляют уникальные образцы украинской сакральной культуры. Не менее важным вопросом является исследование каменного дела, основанное на многовековых традициях использования камня при изготовлении надгробных плит, скульптурных композиций, колонн, обелисков, крестов, икон, различных образцов мелкой пласт ики для отделки захоронений.

Ключевые слова: сакральная мемориальная пластика, православный памятник, плита, культурное наследие, композиция.

Us Viktoriia., Ph.D. of Technical Sciences, Associate Professor of_Interior Design department, National Aviation University

\section{Priority issues of preserving and protecting of Orthodox sacral monuments}

The purpose of the article is to focus the attention of scientists, architects, designers on the urgent tasks of protecting and preserving the cultural heritage of our people - monuments of the sacred art of sacred art, in particular, orthodox gravestones. The methodology is based on a combination of historical analysis of the formation and development of sacred memorial forms, information from art history sources from architecture, sculpture, and decorative art of the 19th - early 20th century. The article used data on the functioning of stone-working and metalworking shop enterprises and specialized workshops for the production of monuments. Archival documents, photo frames, as well as the author's measurements of the surviving tombstones at the Lukianivka cemetery of the city of Kyiv, which provided an opportunity to highlight the most significant issues of this issue, became a weighty basis. Scientific novelty is characterized by the argumentation of the need to begin research on the formative process of Orthodox tombstones from the second half of the XIXth - early XXth century, which remains unexplored today, the formulation of classification features of tombstones, the definition of compositional, technical and technological aspects, the role of formative elements, It is essential in the matter of scientifically grounded methods of restoration, restoration and the design of sacred memorial objects. Conclusions. Priority issues of preservation and protection of Orthodox sacred monuments in Ukraine are formulated on the example of the study of the Lukianivka cemetery in Kyiv. According to external signs of the monuments of the specified period, the main typological groups and dominant elements were established. In the system of qualitative criteria for assessing the shape of a gravestone, the principle of the synthesis of composite, structural, and technological means for constructing gravestones is a priority. The study of products of metal plastics, many of which are in a residual state, confirms that the artistic and decorative and constructive qualities of metal forms of gravestones are unique examples of Ukrainian sacral culture. An equally important issue is the study of steeliness', based on the centuries-old tradition of using stone in the manufacture of tombstones, sculptural compositions, columns, obelisks, crosses, icons, various samples of small plastics for decorating burial grounds.

Key words: sacred memorial plastic, orthodox monument, plate, cultural heritage, composition.

Актуальність дослідження зумовлена нагальною проблемою збереження, охорони та відновлення національної культурно-мистецької спадщини, меморіальних творів сакрального мистецтва, зокрема православних надгробних пам'ятників.

Аналіз досліджень і публікацій. У науковому обігу кількість друкованих джерел, що безпосередньо стосуються проблематики дослідження композиційних i технологічних засад формотворення надгробних пам’ятників, досить обмежена. Причин тому є декілька. 3 одного боку, об'єкти меморіального характеру є своєрідним синтезом архітектури, дизайну, декоративновжиткового мистецтва, технології обробки матеріалів. Тобто в них переплітаються види діяльності, що стосуються духовної, матеріальної, наукової, технічної та гуманітарної культур. 3 другого - в радянські часи, в умовах панування атеїстичної ідеології вивчення даної проблеми було вкрай утрудненим, а публікації на таку тему обмежувалися, як правило, інформацією про історикоархеологічні особливості пам'яток матеріальної культури.

Опрацьовано наукові видання з різних галузей науки й мистецтва, техніки й технологій, що стосуються проблем охорони та збереження та відновлення пам'яток, визначення композиційних та технологічних засад їхнього формотворення. Наближеними 3 погляду проблематики статті можна вважати роботи А. Дороша[2], Л. Проценко[6], К. Поповича[5], М. Станкевича[1]. Практично всі зазначені автори порушували проблеми дослідження історії, стилеутворення, синтезу жанрів, збереження й реставрації об'єктів сакрального меморіального мистецтва. Підсумовуючи, можна сказати, що на сьогодні відсутня цілісна теорії дослідження формотворчих засад православних надмогильних пам'ятників. 
Мета дослідження полягає в акцентуванні уваги науковців, архітекторів, дизайнерів на визначенні першочергових завдань охорони й збереження культурної спадщини нашого народу пам'ятників меморіального сакрального мистецтва, зокрема православних надгробків.

Виклад основного матеріалу. Важливою складовою еволюції суспільства є розвиток культури, що виражається ставленням людини до збереження, охорони та відновлення культурно-мистецьких об'єктів.

Одним із значущих складових культурної спадщини є надмогильний пам'ятник, або, як його називають - надгробок, в якому поєднання змістово-символічної й композиційної будови відтворює ідеали світобачення свого часу.

В Україні одним із таких місць поховання є Лук'янівський некрополь, розташований у Києві, що нині має статус пам'ятки архітектури. Переважну кількість поховань становлять православні надгробки - які на сьогодні, на жаль, є найменш дослідженими пам'ятниками сакрального меморіального мистецтва.

Процес формотворення надгробків як синтетичного поєднання архітектури, дизайну та вжиткового мистецтва сьогодні повинен привернути увагу науковців, громадськості до надзвичайно важливої соціальної, культурної та мистецької проблеми не тільки збереження місць поховань наших предків, а й вивчення історії, рівня духовності, культури народу, визначити напрями, послідовність і коло завдань щодо наукових досліджень у цій справі.

Аналіз морфології більшості православних надгробків приводить до висновку, що основним недоліком їх формування $\epsilon$ відсутність знань про змістову й композиційну основу та художньотворчі принципи їх формотворення. Говорячи про стратегію можливих досліджень, можна зазначити, що правомірним $\epsilon$ системний аналіз композиційних, функціональних, типологічних та конструктивних властивостей надгробків різних типів, який має базуватися на основі натурних обстежень, матеріалах літературних і архівних джерел, використанні наявних методичних практик для подальшого формулювання композиційних засад сучасного проектування.

Історія надгробного пам'ятника пройшла довгий шлях еволюційного розвитку - від простого каменя до справжніх шедеврів світової культури, від кустарного виготовлення простих форм до спеціалізованих майстерень з виготовлення пам'ятників, від примітивних технологій виготовлення до найраціональніших способів видобутку й використання матеріалу, а також вибору засобів його художньої обробки.

Враховуючи географію поширення в Україні православних поховань, їхні кількісні характеристики, об'єктом вивчення зазначених питань обрано надгробні пам'ятники найбільш типового і найбільш масового Лук'янівського цвинтаря міста Києва, історія якого розпочалась за офіційними даними ще 31878 року, а з 1961 року він існує як меморіальний заповідник. За матеріалами наукового відділу заповідника понад дві тисячі могил є складовою Зводу пам'яток Києва, адже містять вишукані витвори мистецтва, створені у майстернях міста кінця XIX - початку $\mathrm{XX}$ ст. Протягом майже століття кладовище стало усипальницею для багатьох відомих громадян та їхніх родичів, а поховання на Лук'янівському кладовищі завжди вважалися особливо престижними [6]. Зауважимо, що значна кількість православних надгробків київського некрополю, і Лук'янівського зокрема, $є$ високохудожніми зразками сакрального мистецтва, які потребують ретельного наукового дослідження, бо внаслідок довготривалого недбалого ставлення до архітектурно-меморіальних об’єктів, багато з них були втрачені, а ті, що залишились, суттєво пошкоджені.

Загальновідомим сьогодні $є$ факт відсутності естетичної концепції надгробка як малої архітектурної форми й невід'ємного елемента культурної спадщини нашого народу. Тому, перш за все, важливого значення набуває з'ясування типології надгробків та вивчення кожного елемента композиційної структури їх кращих зразків.

Зауважимо, що надгробки наділені такими фізичними, об’єктивними властивостями, як об'єм, розміри, вага, форма, матеріал виготовлення. В контексті нашого дослідження найбільш важливе значення має форма надгробка, іiі рукотворний вигляд та положення в просторі, а основним формотворчим елементом i, в той же час-засобом композиції, $\epsilon$ надмогильна плита у своїх різновидах та комбінаціях.

Досить суттєвим є вплив другорядних деталей на визначення їхніх стильових особливостей, до яких належать рельєфи, барельєфи, графіка на порцеляні, урни, вази та амфори, медальйони й картуші, символи, емблеми, гірлянди, монограми й епітафії, ліхтарі, свічники, канделябри, різноманітні геометричні, рослинні орнаменти й зооморфні мотиви.

На сьогодні в проектній практиці створення надгробних пам'ятників склалась ситуація, що підтверджує недостатність або ж фактичну відсутність у проектантів знань про особливості синтезу 
пластичних видів мистецтва, композиційні засади формотворення, правила проектування й зведення згаданих споруд, особливостей їхньої типології тощо. Тому визначені завдання класифікувати ознаки вітчизняного православного надгробка можна вважати цілком мотивованими.

Зауважимо, що багато вітчизняних сакральних пам'яток зведені за проектами відомих архітекторів, художників і $\epsilon$ зразками традиційного, класичного втілення основних правил композиції. Враховуючи кількість формотворчих факторів, що впливають на естетичні якості надгробка як архітектурного художньо-монументального твору, варто здійснити його структурний аналіз. Серед об'єктів, наділених меморіальними функціями, сьогодні найчастіше бачимо плити, хрести, найрізноманітніші скульптурні й архітектурні форми.

Коли ми говоримо про пам'ятник, в основу якого покладено плиту, треба мати на увазі, що остання може бути вертикальною і горизонтальною за положенням; прямокутною, трапецієвидною, багатокутною за своїми геометричними характеристиками; з гострими і заокругленими ребрами; водночас за основними лицьовими обрисами - довільної форми.

Горизонтальні плити у плані та перерізі переважно мають форму прямокутників, з фасками по периметру чи без них, хоча це й не обов'язкова вимога, можливі інші геометричні інтерпретації. Горизонтальна плита може розташовуватись на базі; на землі (база знаходиться дещо нижче рівня землі); плита може бути одного розміру й подібної форми з базою, а може й відрізнятися від неї; містити різні барельєфними або горельєфними зображення.

Плита трапецієвидна особливого представлення не потребує. Зовні вона виглядає як іï звичайний прототип - горизонтальна плита. Наведена характеристика горизонтальних плит $€$ основою для їх проектування й реставрації. Основними матеріалами для виготовлення плит є граніт, мармур, бетон, рідше - метал. Вертикальна плита, як правило, має форму прямокутної призми або зрізаної піраміди.

Значну роль у створенні загальної архітектурно-декоративної композиції надгробку відіграє ордер. Ордерна архітектура втілена у колонних формах, стелах, саркофагах, плоских та просторових портиках, едикулах і може застосовуватися у різних типах надгробків: площинних, об'ємних, арочних, комбінованих та інших. Система ордеру є притаманною, зокрема, багатьом православним пам'ятникам Лук'янівського цвинтаря.

Відмітимо, що монументальна пластика як вид мистецтва розвивається в неподільному зв'язку 3 архітектурно-монументальним будівництвом. Поширення скульптурних завершень використовується з метою декорування та оздоблення надгробків. Незважаючи на участь у створенні скульптурних форм високопрофесійних майстрів, українські зразки сакрального призначення, на думку багатьох вчених, $є$ близькими до традицій народного мистецтва.

Обміри і композиційний аналіз пам'ятників Лук'янівського цвинтаря дозволив авторові цієї публікації зробити узагальнення про те, що в означену історичну добу існування Лук'янівського цвинтаря ціла низка пам'ятників зберігають традиції класицизму. Стильова еволюція меморіальної пластики від класицизму до початку конструктивізму, використання майстрами різних часів різноманітних будівельних матеріалів, технологічних прийомів, інструментарію, композиційних засобів i закономірностей щодо втілення образно-емоційних якостей пам'ятників створили унікальний скарб національної культури, який підлягає подальшому ретельному вивченню.

Як вже зазначалось, переважна більшість меморіальних об'єктів і форм, що збереглись до сьогодні, виготовлялися 3 різних порід каменю. Водночас чимало пам'ятників Лук'янівського цвинтаря $є$ вишуканими зразками художнього металу, який використовується в сакральній меморіальній пластиці для виконання композицій та їх окремих елементів - надмогильних плит, колон, скульптурних елементів, хрестів, огорож.

Питання наукового обгрунтування прикладних $\mathrm{i}$ художніх аспектів проектування надмогильних православних пам'ятників та їх окремих елементів з металу дотепер залишаються розглянутими частково, а в науковій літературі обмаль систематизованих відомостей щодо використання цього матеріалу в сакральних спорудах. [3; 4].

Як відомо, час існування металевих виробів на відкритому повітрі без належного догляду обмежений. Вони втрачають автентичний вигляд, суттєво псуються, видозмінюються і поступово зникають. Треба зауважити, що вивчення зразків металевої пластики, більшість 3 яких є зразками української сакральної культури, наділеними художніми якостями, відкриває значні перспективи в галузі дослідження практичних і мистецьких основ вітчизняної меморіальної пластики не тільки минулого, а й сьогодення.

Вчені підкреслюють спільні стильові, композиційні та семантичні риси меморіальносакральних виробів, виготовлених шляхом художнього ковальства, чавунного й бронзового литва, 
скульптури з металу, що набували специфічних ознак бароко, класицизму, еклектизму, модерну. 3 його багатими металевими формами, які декорували фасади міських будівель, громадських споруд.

Ковальство залишається технічною домінантою у процесах створення пластичних композицій, огорож та надмогильних пам'ятників [4,29]. У композиціях металевої пластики знаходять вираження основні мотиви геометричної, зооморфної й рослинної орнаментики.

Підводячи підсумки, відмітимо, що аналіз особливостей київського художнього металу, різного за функціональним призначенням і технікою виконання, довів наявність спільних рис у композиційній побудові та художньо-образній сфері меморіальних пам'ятників, а саме: розповсюдженість вертикальної, горизонтальної та поворотної симетрії. Аналіз сучасного стану поховань та факт їх маловивченості підтверджує актуальність проведення досліджень надгробних православних пам'ятників, що має сприяти більшій вірогідності встановлення методики їх збереження, принципів реставрації та проектування сучасних форм. Значний пласт інформації становлять матеріали натурних спостережень та звітів про реставрації, здійснених у другій половині XIX на початку XX ст., архівні, іконографічні відомості, зібрані як результат діяльності охороннореставраційних організацій XIX - XX ст., дозволяє розробити номенклатуру й загальну класифікацію православних надгробних пам'ятників. Процеси формотворення надгробних пам'ятників безпосередньо залежать від вибору матеріалу, технології й техніки виконання, а також від рівня професійної майстерності виконавців. Православні надгробні пам'ятники можна умовно поділити на зразки, виконані народними майстрами, й на твори монументального мистецтва, виконані професійними фахівцями за формотворчими закономірностями певного історичного стилю.

У цій публікації увагу приділено найбільш поширеним формам надгробків, а саме: у вигляді плити та iï різновидам, які вважаються архітектурними компонентами цілісного надгробного пам'ятника. У системі якісних критеріїв оцінки форми надгробка пріоритетним $\epsilon$ принцип синтезу композиційних, конструктивних та технологічних засобів їх спорудження. Вивчення виробів 3 металу, багато з яких перебуває в залишковому стані, підтверджує, що художньо-декоративні й конструктивні металеві форми надгробків показують унікальні зразки української сакральної культури. Цим самим ще більше актуалізується проблема спеціальних досліджень практичних i теоретичних питань вітчизняного художнього металу.

Системне дослідження формотворчих засад вітчизняної меморіальної пластики розуміється неможливим без вивчення каменярства, яке грунтується на багатовікових традиціях використання каменю в процесі виготовлення надгробних плит, скульптурних композицій, колон, обелісків, хрестів, ікон, різноманітних зразків дрібної пластики для оздоблення поховань. Характерною рисою розвитку каменярства означеного часового періоду стало злиття народної фігуративної різьби та професійної пластики. Незважаючи на допоміжну роль в композиції надгробків зображальних, знаково-символічних елементів, шрифтових включень, їх вивчення практично не проводилось, що передбачає новий напрям досліджень.

Висновки. Пріоритетні питання збереження та охорони православних сакральних пам'ятників в Україні сформульовані на прикладі дослідження Лук'янівського цвинтаря м. Києва. За зовнішніми ознаками пам'ятників зазначеного періоду встановлено основні типологічні групи, домінантні елементи. В системі якісних критеріїв оцінки форми надгробка пріоритетним є принцип синтезу композиційних, конструктивних та технологічних засобів спорудження надгробків. Вивчення виробів металевої пластики, багато 3 яких перебуває в залишковому стані, підтверджує, що художньодекоративні й конструктивні якості металевих форм надгробків показують унікальні зразки української сакральної культури. Не менш важливим питанням є дослідження каменярства, яке грунтується на багатовікових традиціях використання каменю під час виготовлення надгробних плит, скульптурних композицій, колон, обелісків, хрестів, ікон, різноманітних зразків дрібної пластики для оздоблення поховань.

\section{Jimepamypa}

1. Автентичність мистецтва. Питання теорії пластичних мистецтв: Вибрані праці. Львів. СКІМ, 2004.

$192 \mathrm{c}$.

2. Дорош А. До історії Бруснівського осередку кам’яної пластики. Родовід. 2002. № 1-2. С. 108-111.

3. Малина, В. Кам’яний хрест як дерево смерті і життя. Пам'ять століть. 2007. № 4-5. С. 105-122.

4. Мінжулін О. Подарунок богів. Ковальська майстерня. 2006. № 1. С. 27-32.

5. Попович К.Ф. Нарис історії культури України. Київ: «АртЕк», 1998. 728 с.

6. Проценко Л.А. Лук'янівське цивільне кладовище: путівник. Київ: Інтерграфік, 1998. 144с.

7. Ходорковський Ю.І. Єврейські некрополі України: монографія. Київ: Інтерграфік, 1998. 80 с. 